\author{
ANNA KOKOCINSKA \\ Kazimierz Wielki University, Bydgoszcz \\ a.kokocinska@ukw.edu.pl
}

\title{
TOPOI DISCOURSES OF HIGHER EDUCATION - REFLECTIONS ON EMPIRICAL RESEARCH
}

\begin{abstract}
The text serves as an attempt to summarise the analysis of public discourse which is a part of the research project which considered value of higher academic education in collective consciousness in Polish society. In the analysis of the collected empirical material, methodological directives of qualitative discourse analysis were applied. Main problem presented in the article are topoi that occur both in social and media discourse. It tries to answer the questions why are some ways of speaking about higher education more valid and sustainable than others and what are consequences of such an "use of language" for academic and nonacademic worlds.
\end{abstract}

Keywords: higher education; topoi discourses; diploma value.

The project titled The value of higher education in the collective consciousness of modern Polish society in the perspective of transforming the model of academic education carried out in 2012-2015 ${ }^{1}$ aimed to verify the hypotheses of the gap between the declared and the real value of higher academic education in Polish society and the instrumentalisation of higher education as a consequence of civilisation transformations and the primacy of neoliberal ideology in various spheres of public life, including the sphere of science. The empirical studies carried out for the project included focus group interviews, whose participants were directly involved in the education system ${ }^{2}$; in-depth interviews with respondents directly related to this system ${ }^{3}$ and analysis of socio-political weekly newspapers. ${ }^{4}$

Both group and individual interviews and media materials were analysed by means of interpretations proposed by the researchers to analyse discourse (Abell,

\footnotetext{
1 Project funded by the National Science Centre on the basis of Decision No DEC2011/03/N/HS6/02036.

2 The participants of FGI were parents of students, employers and young people without higher education or willing to study. There were five group interviews completed (quotes indication: e.g. FGI_1).

${ }^{3}$ Interviews were conducted with high school graduates (e.g. SG_1), students (e.g. S_1), graduates (e.g. G_1), lecturers (e.g. L_1), and academic experts (e.g. E_1). A total of 40 IDIs were performed. ${ }_{4}$ The weekly newspapers selected for analysis based on the highest percentage of readers in the group of multi-temporal weekly newspapers with a socio-political profile according to the Polish Reader's Research in the years 2011 - 2013.The analysed titles are: „Newsweek”, „Wprost”, „Polityka”, „Gość Niedzielny”, „Uważam Rze inaczej pisane”.
} 
Meyers 2011, Krzyżanowski 2011). Laclau and Mouffe extend their discourse theory to all social practices, resulting in "discourses and discursive practices becoming synonyms of social relations systems" (Laclau, Mouffe 2007). "Discursive structures are articulation practices («binding practices») that constitute and organise social relationships, and therefore are not merely «cognitive or contemplative beings» (Howarth 2011: 23-24). Thus the whole world of science and the higher education system can be treated, thus filling in the categories of Laclau and Mouffe (Howarth 2011: 160), as a discourse characterised by the functioning of the "set of ideas" (freedom, truth seeking, autotelism and instrumentalism), defined by ,set of practices" (research and educational activities in accordance with established rules) and "reform of institutions and organisations" (2011 Higher Education Reform).

In this study, a number of discourses have been developed around issues related to higher education. Certain visions of academic reality are present in the responses of all groups, as well as in the press articles discussed, i.e. strictly media discourse. The ways of speaking - "use of language" - on academic education in different contexts reflect on the importance and values assigned to it in the Polish society. The dominant interpretative discourse (Touraine 2011: 32) created on the basis of actions and elites: power, scholars, experts and other members of society, and thanks to the representatives of the media world, determines the activity of actors, leading, in the result, to self-renewal and even its deeper anchoring in the supraindividual consciousness.

The analysis of the collected material allowed to distinguish several categories common to the studied spheres, which makes it possible to determine the dominant features of discourse shaping communication activities and influencing the overall picture of higher education. In the studied discourses, there are following topoi: (1) terminological (diploma = "paper"), (2) historical (devaluation of the diploma "today's studies are like pre-war A-levels"); (3) structural (surplus of people with higher education, where ,there are shortages of labour"), (4) economics (work after studies - abroad, through contacts, not in one's profession), (5) cultural ("attractiveness", science as a spectacle).

The first topos, terminological, was distinguished due to the commonplace in the discourses replacement of terms as higher education, to graduate from studies, diploma, with term such as "paper" [In Polish there exist two very similar colloquial terms describing a diploma: "papier" and its diminutive form "papierek", both bearing negative connotations]. Equating a college diploma to a piece of paper, or as in the case of the „papierek", which is diminutive form of word „papier", to a meaningless scrape, reflects a pejorative attitude toward academics. Disrespectful attitude towards higher education visible at the level of language use is due to the conviction of a little power of the diploma. As the studies are now mass, their completion, at least in the generation of twenty and thirty-year-olds, that is the beneficiaries of the educational boom of the 1990s and the beginning of the $21 \mathrm{st}$ century, ceases to be a distinguishing feature of individuals in an increasing number of social environments. Moreover, the reverse trend can be observed - it is considered to be unreasonable to fail to pursue higher education in any form.

The second reason why a diploma is called a "paper" is its declining rank in the labour market because it is not a guarantee of true qualifications. Competences 
acknowledged by the diploma, but not by the practice and experience, are purely theoretical. Employers fear that these skills are only "on paper" and that in fact the potential employee will require additional training instead of immediately taking on the duties assigned to them. Such opinion prevails among the respondents taking part in group interviews. On the other hand, employers often require a formal recognition in the form of a graduation diploma, which the respondents consider to be unbelief in the ability of non-diploma holders and their discrimination because the "paper" itself should not serve as evidence of possessing appropriate qualifications.

On the other hand, graduates who have earned a higher basic salary in the workplace, for example, do not consider this as a merit of academic education, but rather a strange remuneration system for a company that uses rigid payroll principles independent of actual qualifications and work.

"As for the work itself, 1,5 years after graduation, the mere fact of the paper and the title of M.A. before my name [...] gave me 200 zlotys gross more at the beginning, that was the only measurable advantage in my case." (G_7)

The use of the term "paper" also sometimes serves to depress the attitude of students who do not properly fulfil the role of a student, i.e. have a claim attitude or choose to study without a reflection. For this type of students, in the opinion of the respondents, the diploma is nothing more than a compulsory confirmation of graduation without any added value, which results in the assumption of the respondents of the accurateness of usage of this term in this context.

"I think the expectations are that the knowledge should be presented to them, they have to pass the exam and get a „paper", and the whole background should be prepared for them." (L_2)

„I feel sorry for people who do not know why they are going at the university. They have a job and just want a "paper". Nothing more and they want to attend any kind of studies. Maybe they have no idea for themselves. " (S_7)

A diploma as "paper" appears in the respondents' responses to almost all categories covered by the study (not only being used by the experts). In the media discourse, a significant example of the use of the term paper may be the article by Rafał Pikuła Stragany z papierkami [Stands with papers] in which higher education institutions, mainly representing the non-public sector, were compared to marketplaces offering their customers the commodity of a discounted value in terms of both the content of education and a certificate confirming its possession.

"Educational stands products are the most cheesy bubbles: not enough that without any use, they require continuous payment. As if the market trader forgot to mention that the complaint will not be taken into account. " (Pikuła 2012). 
The current graduation diploma is also a "paper" because of the knowledge acquired during the course of study - of lesser extent and inferior quality than in the generations studying, for example, before 1989 or learning in pre-war junior high schools (historical thread). In the face of the rise of a large number of higher schools, soaring increase of students, the traditional characteristics were obliterated, and the number was influenced by the quality of education, since it is impossible to maintain a high level of education when it comes to masses. Once elitist education, even at the secondary level, not to mention the higher degrees, has become completely widespread, which excludes, for example, the direct care of adepts of science. On the other hand, higher education available for almost everybody loses its aura of uniqueness, previously reserved for higher classes, prestigious, distinctive lifestyle as well as ways of participating in public life and culture, from which the state, social and artistic elite were recruited. In the days of the Polish People's Republic, when the social structure was reconstructed, the possibility of advancement through higher education, although it was democratised, was not widespread, and the stratum of intelligentsia appealed, despite the lack of direct roots, to the intellectual ethos of the Second Polish Republic. Currently, heterogeneous group of people with higher education is dispersed in all social stratum. As a result, today's education functions in the discourse as increasingly frail echo of diplomas gained in past historical periods.

"I would not feel pride if I said I have a high school diploma. I think my grandfather, who was born long before the war and had a high school diploma, it was already something. And now these studies often mean less than once a high school diploma. I think it is a deprecation of this title, of this education." (S_4)

It is difficult to give a clear assessment of how much of the visible regret in discourse about higher education gained by previous generations relates to its quality and to what extent its associated phenomena, such as belonging to the elite. Longing for past diplomas and putting them ahead of academically advanced education proves that elitist sentiment remains in the collective consciousness despite the fact that it was the opening of higher education institutions to the masses and the development of the education services market that let the great majority of members of the Polish society, who currently are with higher-education qualifications, gain access to higher education.

Today, we are experiencing a surplus of people with higher education in Poland, which contributes to the structural disturbance primarily in relation to the labor market (structural topos). The structure of education ceases to correspond to the needs of the economy in which the most sought-after are specialised workers, but most often in menial jobs, not requiring a bachelor or master's degree. In hindsight, the abolition of vocational education is judged very badly and its negative effects are felt both in the individual and in the social and economic dimensions. On one hand, labour shortages are the result of an educational policy that encourages general education and limits organisational, technological and financial support for vocational education institutions. On the other hand, it is the result of misguided decisions of young people who prefer to go to "easy" studies, which are contradiction of hard work. Fields of study chosen "for fun" are humanistic disciplines, after which the only option is unemployment or studies run 
by most non-public schools, often referred to as "higher school of cooking and cleaning" (FGI_4). The use of lenient terms in the context of the definition of higher education institutions also demonstrates little social respect not only for schools of dubious reputation for the quality of education but also for the perception of the whole academic community. As a reference to disrespectful submission, also used by Agnieszka Sowa in the article Akademia tego i owego [Academy of this and that] documenting irregularities in one of the public higher education institutions (Sowa 2010). The choice of such a definition, clearly referring to the names of schools operating in the private sector, suggests that they are functioning in the social consciousness as an environment endangering pathologies, so when such phenomena start to affect state schools, these are gaining labels so far reserved for non-public schools.

Exhorting for the reconstruction of vocational education and restoring its position into the place of creation and development of academic education also includes the suggestion of restoring proper proportions in the social structure, i.e. limiting the number of people graduating from universities. Showing in the discourse the negative aspects of excess of graduates, such as the inability to find a job or the weakness of units offering educational services, seems to be an attempt not only to focus on higher education issues in order to overcome them but also to discourage some potential students from unnecessary, from various angles, investments in education. There is no doubt that the acquiring of education is identified solely with the accumulation of resources to achieve the goal, i.e. individual employment where there is real demand reported. The long-term objective of developing a knowledge-based society, which is possible through the efficiency of its members in learning, is a secondary issue in the discourse, if not omitted at all.

Another motive present in all discussed discourses is the relationship between education and later professional work, i.e. economic topos. The instrumental treatment of higher education and its almost exclusively economic value are also manifested in general thinking about conditions in the domestic labour market. First of all, what is relevant to the previously discussed issues is that the education and qualifications of people beginning their careers do not correspond to the needs of employers. The Polish economy is not able to provide highly educated workers, but as mentioned above, it suffers from the shortage of skilled and unskilled workers. As the sphere of education has somewhat outpaced economic progress, the possibility of gainful employment correlates for many people with the necessity to perform tasks for which their competences are not necessary, as confirmed by the thesis of overeducating the Polish society.

„I deeply regret the people who have no chance to work in a profession they like. It may turn out that they do not like what they have studied, and then if they change their profession, it's cool, but then they ask themselves: I studied, and especially when the studies are hard, and there are such, why did they struggle and struggle, because it's ... all over the world it's so that we're not isolated. " (E_4)

The inability to use the skills learned during academic studies in professional work is another reason for the decline in the value of education. In order to be able 
to work in an acquired profession, the only alternative seems to be leaving the country and looking for a job outside of Poland because some specialised qualifications can only be used in other markets. In the social consciousness, whose emanation is discourse, the conviction that only the right connections guarantee a workplace. For the younger generation, such a mechanism of obtaining a job seems to be a natural state of affairs to which they must adapt.

"Studies give a „paper", work gives you contacts. [...] The young have no delusions: it's not so that every man is the architect of his own fortune, your contacts are necessary, deals are important. And anyway they will not work in their profession anyway. They hear it from every side. They believed it themselves" (Ćwieluch 2012).

Elder people, although they are also accustomed to the fact that the family and social affinities are involved in the labor market, refer to this fact with reluctance because their children are slowly entering the labor market. Therefore they consider that the situation in which employment is decisive for their social capital is a distortion of honest, in their opinion, merit-based system.

"M1: If somebody actually finished a particular field, they would try to find a job relating to it, in that field, if they would try hard then I think they find it, it's just a matter of money, and so on.

K3: Well, stroke of luck and contacts”. (FGI_1)

Placing personal relationships with a candidate over a post and their qualifications to perform certain functions is a result of the very low level of social trust in Poland ${ }^{5}$ and the uncertainty faced by members of society towards their actions.

In the discourse, there is also a cultural motif that is related mainly to the "attractiveness" of science. Modern society, and especially its youngest generations, cannot stand stagnation and in the conditions of accelerating civilisation and incessant stimulation they require activity-based learning, attention-grabbing and competition for other activities that focus on the recipient's concentration. The change in this respect is seen from the perspective of the own experience of people studying before the era of domination of pop culture, where digital technology is central.

"K3: Or now, as I hear, the lecturer turns on the presentation somewhere

on the screen and loosey-goosey.

M2: There were no laptops, no computers, no didactic.

K3: But you had to think more". (FGI_1)

At present, at the higher education level, edutainment, i.e education through entertainment, taken as an example form lower levels, is perceived as the only effective model of knowledge transfer. It's not about all forms of entertainment or fun. Emphasis is placed on the diversification of traditional learning methods

${ }_{5}^{5}$ The great majority of Poles (74\%) agree with the statement that in relations with others one should behave very carefully (CBOS: BS/33/2012). 
through the use of modern computer technology, giving, in intent and in the popular opinions, the possibility of interactions between actors in the process of learning and bearing the externalities of modernity. Using the techniques involving many senses of the recipient is an opportunity for educational success, and the lecturers who use them in their didactic work are credible in the eyes of students, as people following the spirit of time, knowing the modern realities and being well aware of them. This gives them some confidence that the knowledge they are passing means more than the "boring" facts that have been repeated for year and being only useful during the exam.

"There is a problem motivating students to study. [...] We have several theoretical lessons, but the program's gem is to simulate the functioning of the economy. I divide the group into several teams, some of them are decision-makers, central bank directors, stock market investors, private entrepreneurs." (G_9)

Activation of students through interactive teaching methods and the "spectacularization" of academic activities is not only a desirable form of learning, but also becomes the only possible one. According to Susan Sontag, modern man remains in a state of permanent numbness, from which only images and reflections can be precipitated, but not words. Images give a sense of confidence in the relationship with truth, "even if it is not essentially a matter of fact and is a visual illusion" (Kubisiowska 2012). Thus the essence is fun, the opportunity to present, the performance of the spectacle, the desire to participate in a given sphere of life in relation to the canons, but on one's own terms.

Debates on the role of higher education and its institutions take on intensity at breakthrough times when higher education institutions formed by society cease to meet the requirements of the new socio-economic order and social forms. The present in the discourse of higher education topoi and strands focus on the changes that are taking place in the higher education system and its reception in the collective consciousness - the devaluation of diplomas, the inadequacy of education in relation to the expectations of the labor market and the changing academic culture. The discussed topoi discourses and discursive practices are rather a negative image of higher education, which in turn leads to a decrease in its value and a gradual decline of autotelity.

\section{REFERENCES}

Abell, Jackie and Greg Meyers. 2011. „Analiza wywiadów badawczych” in Jakościowa analiza dyskursu w naukach społecznych edited by R. Wodak, M. Krzyżanowski. Warszawa: Oficyna Wydawnicza Łośgraf.

Ćwieluch, Juliusz. 2010. „Co się stanie z naszą klasą.” Polityka, April 26, 17:24 - 26.

Howarth, David. 2008. Dyskurs. Warszawa: Oficyna Naukowa.

Krzyżanowski, Michał. 2011. „Analiza zogniskowanych wywiadów grupowych” edited by R. Wodak and M. Krzyżanowski. Warszawa: Oficyna Wydawnicza Łośgraf. 
Kubisiowska, Katarzyna. 2012. „Wszystkie dzieci są nasze.” Tygodnik Powszechny, July 31. Retrived October 17, 2017 (http://tygodnik.onet.pl/ 30,0,77313,2,artykul.html).

Laclau, Ernesto and Chantal Mouffe. 2007. Hegemonia i socjalistyczna strategia. Wrocław: Wydawnictwo DSW.

Pikuła, Robert. 2012. „Stragany z papierkami.” Polityka, October 29, 44: 32 - 34.

Public confidence. BS/33/2012. CBOS. Retrived December 4, 2016 (http://www.cbos.pl/ SPISKOM.POL/2012/K_033_12.PDF).

Sowa, Agnieszka. 2010. „Akademia tego i owego.” Polityka, November 6, 45: 32 33.

Touraine, Alain. 2011. Myśleć inaczej. Warszawa: Państwowy Instytut Wydawniczy. 